\title{
ПРИПОВЕДАЮЕ И РОБНА ПЕТЉА: КА ПОЛИТИЧКОЈ ЕКОНОМИЈИ МОДЕРНОГ РОМАНА
}

\begin{abstract}
Апстракт: У раду се анализирају начини на које робна петља ступа у модерни роман како у тематско-мотивском и идеолошком, тако и у смислу промена у конвенцијама приповедања. Овде су кроз одабране, „теоретичне“ примере (Балзак, Зола, Флобер, Гончаров, Достојевски, Киш, Брет Истон Елис) скицирани могући правци истраживања односа економије и књижевности. Политичка економија романа, заинтересована за тачке мешања, моменте урушавања или рушења чистих категорија, показује да логику уметности романа не би требало окарактерисати као строго раздвајање између патоса материјалног живота и чистоте уметничких означитељских пракси. Она циља на брисање чврсте линије која одваја аутономну и хетерономну уметност.
\end{abstract}

Кључне речи: књижевност, капитализам, естетика, роба, субјективност, модерност, креативност, продуктивност, романтизам, модернизам

Кад је реч о односу књижевности и других области људских знања, уметности и вештина, важно је не губити из вида да књижевна дела не тумаче само писци, књижевни критичари и професори. Начелно говорећи, књижевност претендује на општост која превазилази границе дисциплина и људских способности. Стога је она временом постала легитиман предмет тумачења правника, психолога, антрополога, социолога и економских теоретичара. Потоњи су створили и свој књижевни канон, који обично укључује Шекспи-

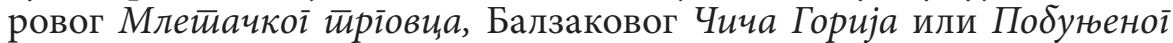
Айласа Ејн Ренд. Али један роман из XVIII столећа постао је најпознатији и најпријемчивији приказ homo economicusa. Усамљени бродоломник Робинсон Крусо за економисте је постао парадигматичан као огољени пример модерног економског човека. Јунак романа напушта дом и породицу због класичних разлога којима би, према економској теорији, требало да се руководи човек капитализма - нужно је побољшати или сасвим променити свој економски статус, а напуштање дома је први корак у остваривању индивидуалистичког животног обрасца. Крусо није смештен у актуелне услове економског живота оног времена већ на пусто острво које је савршена tabula rasa у коју се уписују амбиције економског човека. У овом кључу и речи имају посебна значења. На пример, кад Робинсон на друго путовање понесе a small adventure, то овде не означава тип догађаја већ врсту капитала (Moretti 2013: 25). Adventure значи ризична инвестиција, 
а Дефоов роман је, као што истиче Франко Морети, споменик овој идеји и њеној вези с „динамичном тенденцијом капитализма... да никад не одржава status quо“ (Moretti 2013: 26). Уочивши рано наступање овакве тенденције у трговачком капитализму, Паскал је написао следеће: „Помишљао сам често да сва несрећа људи долази само отуда што не умеју да седе с миром у соби“ (Паскал 1988: 88). Али, као што је познато, Паскал није био економски теоретичар већ протоегзистенцијалистички филозоф који је врло рано наслутио дубинске расцепе унутар модерног субјекта. За класичне политичке економисте, Робинсон, као и друга Дефоова позната јунакиња Мол Фландерс, одражава динамичку тенденцију капитализма: остарели Робинсон и даље тврди како је за њега најнесрећнији део живота био везан за седење. Дефоови јунаци разумеју вредност новца, добро познају технику књиговодствене евиденције, тако да се код њих непрестано наглашава економски индивидуализам, самосталност и независност, односно рационализам понашања неопходан за настанак економског човека.

Класичне економске теоретичаре привлачи једноставност Крусоовог лика као успешног произвођача и потрошача робе и услуга. У изолацији нема друштвених односа, породице, власти, свега што смета „чистој“ економији, тако да је економија Робинсона Крусоа метафора која омогућава либералним економистима да се баве оним што је од суштинске важности за производњу и потрошњу у условима оскудице (Browne, Quinn 1999: 116). Понашање јунака на острву тумачи се као повратак природном животу, он слуша глас природе у себи тако што ради, троши и одмара се у оптималној сразмери, а „његово рационално, прорачунато понашање представља одбацивање традиције, породице и друштва зарад 'природније' везе с материјалним светом“, што одражава историјску и универзалну природу делатног човека (Browne, Quinn 1999: 116). Овде се јавља још једна кључна реч ортодоксне економије: корисност. Хегел језгровито у Феноменолоїи gуха описује просвећеност следећим речима: овде је „све корисно“, а чини се да би то могло бити и Робинсоново гесло. Враћајући се на брод након бродолома, јунак скупља све оно што је корисно за њега (Moretti 2013: 35-36). Корисно је овде категорија која утврђује приватно власништво (корисно за мене), односно оно што легитимише приватно власништво (корисно за мене): „у краљевству корисног, нишй а није сврха по себи - већ је само средство за постизање нечег другог. Алат. А у свету алата, остаје да се уради још само једно: да се ради“ (Moretti 2013: 36).

Роман у први план ставља значај рада за људски живот, што је једна од великих тема ортодоксне економије. Поставивши јунака у природно окружење у коме мануелни рад игра главну улогу, Дефо је вешто вратио уназад економски часовник. Робинсон заиста јесте вредан, он се врло мало одмара, ради квалитетно и истрајно, како 
би на острву корак по корак устројио „нормалан“, „цивилизован“ живот. Његов однос према раду је донекле у вези и са ширењем протестантизма - то је и иначе важна тема у опусу Данијела Дефоа - у коме постоји тенденција одбацивања раније хришћанске идеје да је мануелни рад божја казна. Сада рад више није казна већ човекова дужност, чиме се ствара један од нужних предуслова за развој индустријског капитализма у XIX веку. Као што пише Вебер у Пройе-

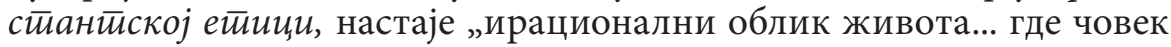
живи због свог посла, уместо обрнуто“ и где је једини исход нечијег непрекидног рада „ирационални осећај да је посао добро урађен“ (Moretti 2013: 43). О том преображају сведоче и материјалне чињенице, рецимо да се током XVIII века број радних дана повећао са 250 на 300 (Moretti 2013: 29). Заједно са Франком Моретијем морамо поставити питање: зашто Робинсон толико ради? Исти аутор нуди објашњење у историји и противречностима самог грађанства: он ради за себе као да је он сам неко други. Наиме, једна његова страна постаје занатлија што проводи седмице како би нешто постигао, а потом се појављује Крусо господар и указује на недовољност постигнутог (Moretti 2013: 30). Радити за другог као за себе је веома важан моменат у развоју капитализма. Тај круг се непрестано понавља и то зато што је рад постао нови принцип легитимације моћи у друштву. Тематизација рада је уистину новина, ниједан романескни јунак не ради колико Робинсон, али рад служи томе да оправда, односно легитимизује његово стицање: не заслужује ли он све оно што је стекао? (Moretti 2013: 30). Оправдање за рад налази се у идеји удобног (comfortable): ако је 'корисност' острво претворила у радионицу, 'удобност' поновно успоставља елемент задовољства у Робинсоновој егзистенцији (...)“(Moretti 2013: 45).

Па ипак, ова наизглед идеална прича о homo economicusu, чији пун наслов гласи Животи и чуgесне изненађујуће йустиоловине Робинсона Крусоа из Торка, морнара (найисао он сам), испуњена је проблемима својственим капиталистичком подухвату. Тиме се потврђује поставка Марка Шела из утицајне студије Економија књижевносиии (1978): „књижевна дела се састоје од ситних тропичких размена или метафора, од којих се неке могу анализирати у смислу означеног економског садржаја и које се све могу анализирати у кључу економске форме“. Економска књижевна критика настоји „да разуме однос између таквих литерарних размена и размена које творе политичку економију“ (Shell 1978: 7). Из овог угла би се, спајајући анализу форме и садржаја, могло тврдити да је јунак попут Робинсона сасвим очекивано у средишту пажње романа јер су индивидуализам, рационалност и самоинтерес у срцу ортодоксне економске теорије. Под-

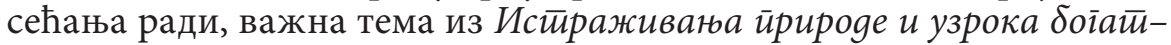
стива нароgа Адама Смита је способност одрицања од краткотрајне награде због изгледа на дугорочну корист. Романом влада речник 
телеологије (сврхе, циља, средства, спремности) ослоњен на оно што је Вебер назвао Zweckrationalität - рационалност којом руководи њен циљ и којем циљу је она усмерена. С тим је повезан Дефоов допринос у смислу технике писања јер он развија прозу као стил корисности (Moretti 2013: 39).

Међутим, управо ако логику размене о којој говори ортодоксна економија доведемо у средиште пажње почећемо да разобличавамо мит о Робинзону као економском човеку, односно као субјекту који је репрезентант универзализма и идеологије модерног капиталистичког подухвата корисног за све. Видећемо да се овде превиђају „елементи принуде који су играли важну улогу код продора капитализма“ (Кока 2016: 73). Најпре, уколико подробно читамо роман, лако ћемо утврдити да не-економски фактори скоро нимало не утичу на Крусоове односе према другим људима. У људима искључиво види робну вредност, процењује колико су они употребљиви, али је још важније што он тај свој однос посматра као потпуно савршен, живећи у уверењу да је Петко срећан, као што и Ксури својевољно, такорећи рационално, прихвата да буде продат у ропство. Поврх тога, у роману се жена третира на нов начин. Наиме, док су се раније, још од Oguceje, за ненасељена острва углавном везивале фантазије о женама, у Робинсоновом опису боравка на острву та тема је готово сасвим искључена. Јунак жали што нема друштво, али он не тражи женско друштво већ чезне за мушким робом; кад се појави Петко, Робинсон има све услове које је тражио. Али само из његовог личног угла јер прича подразумева насилно стицање: посматрано на тај начин, први део Робинсона Крусоа је „савршена илустрација пустоловног менталитета раномодерне трговине у далеким деловима света“, која је укључивала неизрачунљиве ризике (Moretti 2013: 26), али и насилна присвајања.

Млади Робинсон Крусо се, сходно томе, може посматрати као симбол „истинског почетка данашњег света“ (Moretti 2013: 27), али не на начин како нас уверава отродоксна економска теорија. Капиталистичка рационализација повезана је с европским колонијализмом, насилно стицање је опстајало паралелно с модерном рационалношћу (Moretti 2013: 42). Поврх тога, Крусо не може бити репрезентативни агенс, насупрот наводној универзалности економског човека, његов лик је „мушки“, насупрот женственом свету острва и ирационалном, „меком“, слатком и детињастом Петковом свету. Крусо је агенс који има слободу да присвоји и контролише ресурсе пасивних и инфериорних других (природе, колонијалног субјекта Петка, жене која одржава његово домаћинство након што је коначно напустио острво, робова на његовој плантажи шећерне трске у Бразилу који му омогућавају да се обогати у одсуству) (Browne, Quinn 1999: 116). Одавно су феминистичке економисткиње уочиле да је универзални субјект којег, према економској теорији, треба да 
представља Крусо у ствари партикуларни, маскулини субјект који је друштвено конструисан у дискурсу западне науке и филозофије: он делује у свету расизма и експлоатације који је теоријски у сукобу с идеалима слободног тржишта који економисти по правилу повезују с причом о њему (Browne, Quinn 1999: 116). Дефоов роман је велики модерни мит, али он је то упркос његовим пустоловинама, а не због њих (Moretti 2013: 28). Овај роман открива, према Моретију, кључну структуралну противречност капитализма: рационални буржуј неће никада сасвим прерасти ирационалне импулсе (као што је мислио Вебер), предатор у њему никада неће умрети (Moretti 2013: 35).

Стога не чуди што је у Дијалектиици конкретиной Карел Косик своју дискусију о односу економије и филозофије започео следећим ставом: „Првобитан и елементаран начин у коме постоји економија за човека јесте брига“" (Косик 1968: 84). Брига се, према овом схватању, односи на неминовну уплетеност индивидуе у мрежу односа која се пред њом представља као практично-утилитарни свет и која, будући да фетишизује будућност, обезвређује садашњост. Слично би се могло рећи и за ступање економије у роман, она и у њега ступа као брига, као свет који се прелама у субјекту/тексту и распоређује и кроји индивидуални живот ликова и ритам писања. Модерни роман и политичка економија јављају се у исто време, што је оставило низ крупних последица које се могу пратити до данас. С једне стране, књижевност и економски диксурси од XVIII столећа деле сличне бриге везане за променљиву природу естетске, културне и монетарне вредности и настоје на неки начин да их стабилизују (Comyn 2018: 3). С друге стране, често се сматра да књижевност не одражава економски начин размишљања, док економисти не признају аналитичке вештине књижевних аутора (Watts, Smith 1989: 291). Ова два становишта се сажето могу изразити на следећи начин: (1) као и сви други елементи стварности, књижевност је у власти економских законитости, а истраживање би требало да утврди начине и типове такве зависности; (2) између књижевности и економије влада раскол, а књижевно проучавање требало би тај раскол непрестано да потврђује. Раскол налази порекло у класичној економској науци која је „економском човеку“ подарила као основне карактеристике рационализам понашања и егоизам. У систему Адама Смита људи су истргнути из природних и моралних веза, њихови односи су „потпуно уговорни, изражљиви и оцењиви у новцу“ (Косик 1967: 111), а знаменити егоизам вреди само у оквиру система у којем човек пошавши за приватним интересима остварује корист за све. Кључни проблем ортодоксне политичке економије је кружност њеног главног аргумента: корист за све која се јавља као резултат економског процеса почива на идеологизованој премиси да је капитализам најбољи могући систем (Косик 1967: 106).

Рекло би се да је право порекло поменутих супротстављених ставова (1) и (2) у располовљености која од почетка карактерише 
капиталистички свет: с једне стране је свет наводне објективности (власништва, прорачунатости, управљивости, савладљивости, егзактности, научности, квантификације, овладавања природом, корисности), док је с друге стране свет субјективности (уметности, унутрашњости, лепоте, људске слободе, религије) (Косик 1967: 118). Да ли је онда могуће два толико различита става поставити у једну алогичну реченицу, али такву која је често предмет вере књижевних проучавалаца, а не њихове рационалости: иако је књижевност у власти економских законитости као и сви ми, она је изнад њих, другачија од њих, или је пак у сукобу с њима. Уврежена је представа да је књижевност одвојена од економских сила, или да барем није непосредно зависна од њих; па ипак, у данашње време непрестано и прилично успешно нас убеђују да је зависност од економије свепрожимајућа. Ако књижевност према стварности баштини критички однос, онда она мора да нађе начин да изађе на крај с распрострањеном економистичком предрасудом, односно с економизацијом читавог друштва у коме апсолутно доминирају речи из економских дискурса - интерес, тржиште, камата, добит, успех, популарност и сл. Но и она сама мора, како се чини, непрестано да преиспитује предрасуде о властитом имунитету, односно о надређености и аутономији која извире из подједнако арбитрарног извора као и аутономија економске науке (на ову тему ћемо се вратити на крају текста).

Наука политичке економије настала је у исто време кад и роман као типична књижевна форма грађанства. У сваком случају, постоји веза између економске теорије и романа, макар и зато што су они повлашћени простори представљања друштвене стварности унутар трајне дебате о кризи вредности у модерности: „убрзани раст и институционална консолидација трговачког капитализма у XVIII столећу створили су тражњу за новим описима и оправдањима за економију, државу, морал и грађанска права, тражњу коју су задоваљавали... како област политичке економије, тако и роман“ (Kaufmann 1995: 169; в. Comyn 2018: 4). Током XVIII столећа, „концепт вредности пролази кроз дубински преображај и био је преобликован у складу с различитим хуманистичким, финансијским и естетским дискурсима које познајемо данас“ (Thompson 1996: 1), али чији је крајњи исход, будући да су морални кодови повезани с обликом власништва, било одвајање етичких од економских питања. То показује и Сара Комин у компаративном читању романа и

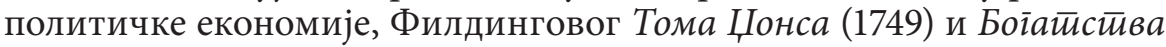
нароgа Адама Смита (1776), како би објаснила на које начине проза разрешава у то време растућу напетост између традиционалног власништва над непокретностима, с једне стране, и појаве кредита и све веће флуктуације новца, с друге стране: у Филдинговом роману на крају побеђује стари облик власништва, што је, разуме се, само 
пролазна победа фикције (Comyn 2018: 35-62). Слично томе, Дикенсова Велика очекиваға (1861) тематизују рађање друштва у индустријском капитализму кроз сукоб наследног богатства са силама тржишног капитализма. Изгледа да од почетка фикционална проза боље од других дискурса показује у којој мери су морални кодови повезани с обликом власништва. Наравно, јасно је да су и економија и поезија творевине људске праксе, па стога обе морају да се суоче с општим проблемима, као што је, на пример, проблем представљања, чиме већ поменута брига постаје још снажнија.

Мора се зато узети у обзир још једно кретање у овом раздобљу, повезано с разумевањем позиције „писац“. У време пре постојања књижевног тржишта, кад је писање било зависно од аристократских покровитеља, оно је посматрано као занат, сличан другим занатима повезаним с производњом књиге као што су књиговезац или словослагач. Писац је у рано модерно доба још увек био мајстор који спретно влада одређеним скупом правила и техника који су вековима преношени у настави реторике и поетике (Woodmansee 1994: 35-55). Повећањем броја читалаца и растом тржишта „лаке“ књижевности за забаву и разноразне практичне савете, издавачи почињу да плаћају ауторима за права на објављивање књиге (Osteen, Woodmansee 1999: 6). Тиме се ствара основа за капиталистичку економију слободних писаца утемељену на продаји писане речи на тржишту. Наравно, ово је довело до реконцептуализације писања, односно до још једног познатог двојства: друштвени аспект уступа пред индивидуализмом захваљујући надметању на тржишту, али се исто тако јавља негативан став елитних писаца прематржишној економији, па чак и према самом друштву као „маси“.

У ствари, збива се дубинска промена чије последице трају до данас. Модерна књижевност се за разлику од традиционалних концепција развијала у режиму унутар којег је њен повлашћен положај од почетка угрожен, али је компензација за ту угроженост начелно веровање да сваки субјект може да постане стваралац, а сваки предмет леп. Романтичарска и модернистичка књижевност изразила је веру у конститутивну моћ маште, изградила је поверење у способност књижевности да наметне поредак, вредности и смисао хаосу и расцепканости друштва које се убрзано модернизује. Еманципацијски потенцијал књижевности био је несумњив: она је евоцирала хоризонт општости и могућност привилеговања личног искуства, занимање за дубину сопства, за сложену унутрашњост модерних субјеката, али још увек у контексту обећаног заједништва. У позадини овакве еманципације налази се аксиом једнакости: књижевност делује на основу претпоставке да свако говори сваком, да је сваки облик дискурса у начелу на располагању сваком. Модерност значи пад хијерархијског, религијског и метафизичког начина организовања и легитимизације културног поретка. Нормативна осно- 
ва за социјалну структуру и организацију се у XIX столећу пренела из вертикале у хоризонталу, од друштвеног поретка утемељеног на рангу ка оном утемељеном на људском достојанству. Интелектуалци су ослобођени обавезе да обезбеде естетску подршку хијерархијском свету традиционалне религије, али сада траже ново духовно уточиште, првенствено под геслом романтизма као квазисекуларне религије уметности, која је успутна станица у повратку изгубљеном свету заједништва унутар атомизовања које намеће капитализам.

Међусобна веза једнакости и уметности у том контексту је незаобилазна тема јер се не може одушевљено говорити о једној а да то не буде на уштрб друге, и обрнуто. Овде се идеја о еманципацијском потенцијалу књижевности ослања на континуитет између једнакости индивидуа у политичком и једнакости грађе, стилова и тема у естетском пољу. Сходно томе, питање политичке и списатељске еманципације су две стране истог новчића модерности, а и на сличан начин се постепено одвајају од економије. Водећи писци XIX столећа, као што су Балзак, Флобер, Достојевски, Зола, Дикенс или Ибзен, стварају суверену слику савременог друштва, што им даје важну улогу у режимима друштвене, односно политичке видљивости. Стога је писац, иако заговорник индивидуалности, био у „природној“ вези с нацијом (државом, друштвом, заједницом), која је служила као мост изграђен између изузетног појединца и заједнице, утемељен на идеји заједничког језика, културног идентитета, наслеђа и слично. Раскол књижевности и капитализма збива се, дакле, на нивоу општости у који још увек верује књижевни човек насупрот егоизму економског човека, који тек посредно, путем властитог егоизма, циља на заједничку корист.

Упркос утиску да су писци изражавали нове облике друштвеног устројства, ваља узети у обзир и да су они редом велики критичари тог истог друштва јер смена представљачког режима уметности естетским режимом (Rancière 2007: 12-30), уноси особену напетост у однос специфичног и општег и сведочи о широј промени режима чулности. Главни покретач те напетости долази из економских односа и повезан је с успоном робног друштва, односно онога што називамо робна петља (в. Лошонц, Гвозден 2008: 100-119). Роба као темељ капиталистичких друштава није статична, она постаје елемент света само кад је у покрету, у процесу, у размени унутар специфичних друштвених односа који творе сложену мрежу. Реч је о „најтемељнијој структуришућој форми капиталистичког друштва, о форми коју твори историјски детерминисан облик друштвене праксе“ (Postone 1993: 44). Уколико се одвија процес комодификације ресурса, производа, функција и могућности, онда би требало да размишљамо шта тај процес мења у конкретним областима, као што је писање романа. Сходно томе, главно питање је који је прави, смислени контекст задобијања робног карактера, односно како 
доћи до литерарне интерпретације утемељене на интелигибилности модерног света посредованог робом.

Прве назнаке појављивања робне петље везују се за Француску почетком XIX века, али се она коначно устоличава на прелому векова у богатим земљама западне Европе и у Сједињеним Америчким Државама, премда неки њени аспекти постепено овладавају и другим деловима света. Током раздобља последње трећине претпрошлог столећа, роба се више не појављују у рудиментарној форми већ почиње да нуди „све блиставију и тананију оплату која све више обећава и све мање нуди“ (Фриц Хауг 1981: 29). У овој новој конструкцији друштвене реалности, роба почиње да гради монументална окружења у којима сама куповина постаје пријатна делатност; куповина постаје чак доколичарска активност; у роби сада нешто фасцинира, развија се нова перспектива, настаје оно што зовемо „робна петља“, поглед у којем се богатство грађанског друштва појављује као огромна збирка робе (в. Лошонц, Гвозден 2016: 13-54). Наравно, ова промена је трагала за новим типом људи с усађеним концептом потрошње као необичног чулног искуства. То искуство могло је да буде сродно машти романописаца: један провинцијски трговац 1810. године посетио је лондонски Сити и све га је подсетило на фантастичне светове из Гуливерових йуйоваюа (Alexander 1970: 162-163; Carrier 1995: 79).

Немогуће је довести у питање значај романа у човековом самообликовању. Теоријски је труизам да је модерни роман социологичан жанр и да су његови јунаци уроњени у сложену мрежу етичких, емоционалних, културних и друштвено-економских фактора који утичу на њихове акције. Моретијев став да је роман „велика антрополошка сила, која је читање претворила у задовољство и редефинисала осећај стварности, смисао индивидуалне егзистенције, перцепцију времена и језика" (Moretti 2006: ix), може се прихватити, али се непрестано мора указивати на амбивалентност и комплексност односа књижевног писања и економског деловања. Разуме се да сложени однос романа према економији и класној структури значи да контрадикције унутар његове конструкције могу да укажу на страхове и сукобе који постоје у друштву (Comyn 2018: 6). Правци и начини деловања робне петље у роману су разнолики, што отежава свако једнозначно разумевање односа књижевног писања и економских процеса. Уочљиво је, пре свега, да од XVIII века дотадашњи наративни идеализам пролази кроз дубинске преображаје, а идеали све више постају интериоризовани, такорећи затворени унутар четири зида грађанског дома. Тако, рецимо, Jagu млаgо̄ Веріиера (1774) означавају успон новог песимистичког идеализма, који препознаје како величину изабраних душа, тако и њихову немогућност да се остваре у стварном свету (Pavel 2006: 21). Ни у соби више нема мира на који се век раније позивао Паскал. 
Хегелова „проза света“ постаје део романа који сада укључује све спољашње факторе који ограничавају индивидуалну слободу и независност, ометајући више тежње духа (Ginsburg, Nandrea 2006: 244). Свет прозе и свакодневице је контингентан јер је индивидуа везана за контекст, она се не може разумети из себе саме већ увек из нечег другог, али то друго губи стабилност карактеристичну за митске обрасце. Како се контрола над животом губи у новом комплекситету робне петље, тако се мења и субјект: „Друштвени склад се не шири даље од опонашања жеља других; потребни су други да би се знало шта треба желети, а у исто време треба те друге уклонити како би се овладало предметима које су они означили нашим паразитским апетитима“ (Берсани 2002: 56). У романима из XIX века писаним у трећем лицу готово увек постоји слична асиметрија: протагониста је стављен у први план, док су мањи ликови интегрисани у причу тако што су подређени као индивидуе (Woloch 2006: 305). Како опада вера у субјективну контролу, у наратив ступа све више нестабилности и контингенције и он све мање еманира из лика који је уписан у причу. Најпознатији пример за то јесте Балзак код којег су друштвени односи, изражени кроз успон и пад јунака, повезани с низом неповезаних и тривијалних чињеница које потичу из врло различитих извора унутар једне сложене друштвено-економске мреже. То је све појачано и познатим техничким решењем: јунаци прелазе из романа у роман. Балзаков романескни свет је типичан прозни миље ране фазе устоличења робне петље: ништа није независно, ништа није јединствено, непоновљиво или апсолутно, све је у вези с другим стварима које су подједнако зависне (Ginsburg, Nandrea 2006: 25). А ако је Балзакова проза почетак, Џојсов Уликс (1922) могао би се посматрати као израз довршења књижевне форме која прати раст и усложњавање робне петље.

Капитал у XIX столећу продире у све сфере живота, али и ствара нове паралелне универзуме. Може се тако, рецимо, говорити о бодлеровској фази историје европског индивидуализма управо из угла деловања робне петље. Средина века донела је кључни рез: Цвеће зла и Госйођа Бовари најављују појаву аутономног књижевног поља где текст „може бити леп, не само упркос аспектима у којима није добар већ у самом том аспекту“ (Moretti 2013: 140). Политичка економија прозе друге половине XIX века добро показује да естетски став, односно естетско искуство „продуховљује“ искуство робе. Стога је дискусија о уметности неизбежна у сваком говору о роби јер живети у свету који изгледа као огромна збирка стварне или потенцијалне робе значи обдарити објекте означитељском праксом која нема никакве везе с њиховим корисним својствима. Према познатој тврдњи Валтера Бенјамина, структура савременог искуства задобија естетске облике, чиме се добија упоришна тачка за деконструкцију размака између економије и естетике која кулминира у касном капита- 
лизму: Бенјамин је, примера ради, посматрао Бодлера као песника усред капиталистичког прекрајања улица и тргова, док је Олдус Хаксли деценијама касније писао да је у економији добро устројена фабрика „еквивалент лепо сазданог уметничког дела“ (Huxley 1959: 38). Није естетизација капитализма тек плод епохе коју данас зовемо касним капитализмом: робна естетика као важан аспект робне петље је његова иманентна црта, а сходно томе она је и неизбежни део политичке економије романа.

Једна од уобичајених „оптужби“на рачун књижевности гласи да је романтизам допринео ослобађању потрошачке жеље и увођењу естетских образаца у свакодневно искуство. Ову дијагнозу, између осталих, износи Колин Кембел у књизи Романйичарска етичка и gух моgерноі конзумеризма (Campbell 1987), мада је још Маркс приметио да цена робе „намигује као заљубљено око“ (Маркс 1977: 251). Романтичарски писци су хвалили емоцију и индивидуализам, говорили су о значају љубави и патње, величали женску лепоту. Кембелова теза гласи: додир с оваквим вредностима, који се одвијао превасходно читањем сентименталистичких романа енглеских, француских и немачких аутора, подстакао је успон конзумеризма; у овом кључу дискурс љубави је веома важан за потрошњу, као и за подизање квалитета искуства (в. и Luhman 1982: 47; Illouz 1997: 6-11; Džej 1982: 173). У XIX веку се све више наглашава одговорност жене за лепоту, а породица ступа у средиште афективног односа; робна петља се умножава захваљујући новим предметима за декорацију дома или литературом за домаћице. Кембел доводи у везу хедонизам и потрошњу оцењујући да романтизам ужитак поставља као вишу вредност од повиновања правилима друштвене игре. Људи су у потрошњи почели да виде начин да изразе своју индивидуалну суштину, чак и начин да стимулишу емотивне односе и развијају приватну сферу. Као што каже Волфганг Фриц Хауг у незаобилазној Критичии робне естиетике: „(..) љубавна драж је једна врста јаких дражи којима робна производња оперише у сврху оплођења капитала.“ Роба позајмљује од људи свој естетизовани језик ради придобијања љубави, али однос се преокреће па сада људи свој естетски израз преузимају од робе, што доводи до снажне спреге употребног облика робе и људске чулности (Фриц Хауг 1981: 13).

Као једно од главних поља саучесништва уметности с робним друштвом или робном петљом обично се обележава ширење простора жеље или, боље речено, процеси њеног ослобађања и њене демократизације који су обележили ово раздобље - између осталог, средином XIX века јавља се и подела на примењене и лепе уметности. Робној петљи била је потребна култура како би повећала и тотализовала властити значај. У ствари, може се тврдити да је робно друштво резултат чврсте повезаности економске и културне сфере, чиме се оспорава супротстављеност становишта (1) и (2). Како уоча- 
ва Лефевр, корисник (потрошач) постао је стециште „културе“, односно мешавине идеологије, представа и знања. Ако огромна културна индустрија пружа специфичне производе које корисник има „право“ да бира, онда производи управо престају да изгледају као робе, и постају посматрани као предмети који сами себе вреднују (Lefebvre 1988: 557). Робу је требало укључити у културни систем и доделити јој естетску функцију - што добро показује пример Еме Бовари, жене са села која пропаст љубавних авантура компензује куповином естетизованих предмета:

Једна жена која је себи наметнула тако велике жртве могла је себи да дозволи неке лудости. Она себи купи готско клецало за молитву, а за месец дана потроши више од четрнаест франака на лимун за негу својих ноктију; писала је у Руан да јој пошаљу хаљину од плавог кашмира; код Лереа је одабрала најлепши појас; везивала га је око струка домаће хаљине; и тако дотерана, са затвореним капцима на прозорима, лежала би испружена, с књигом у руци. (...) Хтела је да научи италијански, купила је речнике, једну граматику, хрпу беле хартије. Покушала је да чита озбиљна штива, из историје и филозофије (...) (Флобер 1988: 145).

Робна петља подразумева особену политику разочарања: патим, дакле, купујем - то је већ био слоган Флоберова Еме Бовари. У том кључу, госпођа Бовари, то смо сви ми (а не само Флобер).

Кад је Рансијер поставио питање зашто је требало убити Ему Бовари, циљао је на модерну супституцију предмета жеље. Он одбацује стандардно тумачење према којем је Ема Бовари побркала књижевност и живот и креће се у правцу економских узрока њеног пада (Рансијер 2008: 53-70). Према Рансијеровој анализи, романескна својства подударна су с главном интелектуалном опсесијом оног времена, коју најбоље сажима реч узбуђење, што нас враћа Кембеловим тезама о романтизму. Али уместо позитивне улоге унутар поетике једног књижевног периода, у Француској средином XIX века, она је постала име за друштвено зло оличено у непрестаном вртложењу апетита, фрустрација и жеља. Стари поредак уништили су нови повесни токови оличени у наслеђу Француске револуције, индустријализације и нових медија (јефтине и лако доступне књиге, новине, часописи, литографије). Друштво све више постаје непрегледна мешавина слободних и једнаких појединаца које непрестано увлачи вртлог потраге за узбуђењима. Та мешавина добија име „демократија“, а Ема Бовари постаје код читалаца, укључујући и њене прогонитеље, оличење те „демократске жеђи“.

Ема, дакле, жели све и изједначава све са свачим. Али то чини и њен двојник, писац Флобер, јер сада роман све меша, нема поделе на поетске ствари и прозаичне ствари, све је достојни предмет приповедања и „стила“. Најбаналнији моменти свакидашњице постају поглавља романа (Moretti 2013: 76). Писац меша устаљене категорије, 
горко постаје слатко, високо ниско, а за економску анализу текста је посебно важна танка граница између отрова и лека, оличена у једној од типичних колонијаних врста робе - у шећеру. Као што је познато, Ема се отровала арсеником, чији је симбол $A s$, а атомски број 33. Наиме, апотекаров шегрт био је раније оптужен да је уместо шећера умало донео арсеник како би се пошећерио џем који је припремала апотекарева фамилија. Знајући за ову епизоду, Ема је узела отров из апотекарске лабораторије, из Омеовог „светилишта“. Како би „покрио“ чин Еминог самоубиства у евентуално властиту одговорност, бескрупулозни Оме тврди да је јунакиња, правећи крем од ваниле, грешком узела арсеник уместо шећера (Флобер 1988: 370). Уклештена у подземно деловање робне петље, Ема умире горком смрћу од горког арсеника који се, због сличног изгледа, парадоксално брка са слатким шећером, испуњавајућу судбину коју је видела у руанској опери, у Доницетијевој Лучији og Ламермура. Тако се њен живот, мотивисан књижевним обрасцима, завршава на сличан начин, само унутар опере (која увек подразумева и књижевни текст). Флоберова улога је кључна за развој политичке економије романа јер исписује прозу, чији је темељ рад а не надахнуће, уз актуелизацију крхке опозиције између уметности и „прозе света“. У ствари, могло би се тврдити да је Флоберова романескна политичка економија савршена пукотина: „јерес супституције“ на плану садржаја поновљен је на плану израза. Роман Госйођа Бовари јасно је показао како су песничке и романтичне тежње сопства уклештене у прозаичну стварност робне петље. Али та стварност је фундаментална стварност.

Тако стижемо до одговора на почетно питање. Ема Бовари је морала бити убијена, јер је починила преступ против уметности. Тај прекршај се, према Рансијеру, зове естетизација обичног живота и темељи се, у нашем разумевању, на супституцијама насталим под притиском робне петље. У роману се непрестано збивају различите диференцијације између робне петље и уметности. Тако, рецимо, јунакиња брка уређење куће с књижевним дискурсом:

Претплатила се на женски лист Корбеј и на Силф gе салон. Гутала је, не прескачући ништа, све вести о премијерним представама, свим коњским тркама и приредбама, занимао ју је први наступ неке певачице, отварање нове радње. Знала је за нову моду, адресе добрих кројача, за дане кад се одлазило у шуму или у оперу. Код Ежена Сија је простудирала описе намештаја; читала је Балзака и Жорж Санд, и у њиховим делима тражила замишљено задовољство сопствених жудњи. (Флобер 1988: 68)

Како се чини, часописи служе томе да се побрка књижевно дело с нечим тако обичним као што је уређење ентеријера. Према Рансијеру, злочин Еме Бовари није, разуме се, прељуба већ злоупотреба једнакости уметности и живота: „Књижевност је мора погубити како би заштитила уметност од њене злокобне двојнице, естетиза- 
ције живота“ (Рансијер 2008: 63). Можемо ли ипак Емину кривицу пребацити на деловање робне петље, или је њена кривица што није деловала интерактивно већ је само пасивно прихватала рад робних супституција, чији је неизбежни део суочавање с непријатним књиговодственим чињеницама. (Коначно, могло би се тврдити да је госпођа Бовари лош књиговођа!)

Чињеница је, дакле, да од XIX столећа и успона индустријске производње роба зачарава свет доносећи обећање профаног уживања. Као последица тог процеса, естетика је престала да се одређује као нешто што има везе с лепим већ шире, као нешто што упућује на чулно искуство, односно чулно богаћење и, као што смо видели, узбуђење. Рансијер наводи низ незаобилазних примера естетизације свакодневице и нових „употреба“ уметности, које се, у нашем тумачењу, могу посматрати као етапе устоличења робне петље. Жан Дезесент из Уисмансовог романа Насуйрой (1884) жели да живи окружен пробраним уметничким делима и различитом необичном робом, попут ретких мириса или невероватних биљака (Рансијер 2008: 63). Толстојева Кројцерова сонатиа (1889) данас, кад је порнографија свуда присутна, можда делује гротескно, будући да Бетовеново велико дело музичке уметности служи, према мишљењу јунака, сексуалном надраживању његове супруге у друштву виолинисте с којим вежба. Овоме Рансијер придружује и Флоберовог великог књижевног сродника Пруста, који естету Свана жени приглупом полумонденком коју овај воли зато што му личи на један Ботичелијев лик (Рансијер 2008: 64). Утолико се може прихватити да роман саучествује у дуготрајној динамици одређивања пажње у капитализму. И уколико се роман сукобљава с устаљеним облицима каузалности, темпоралних и просторних образаца, као и персоналних диспозиција, његова постигнућа морају се довести у везу с преображајем пажње јер и сам капитализам јесте социо-економска технологија уређивања, кројења објеката пажње.

Објекти као роба су неутрални и имперсонални, а њихове вредности су апстрактне: да би они постали смисленији, потребно је изменити, прилагодити чулност. Сходно томе, да би формални модалитет субјективног избора функционисао, потребан му је суштински квалитет - а то је емоција, односно премештање акцента с произвођача и својстава саме робе на њеног купца. Иако се снажне силе ослобађају још у XIV веку, кад роба знатно лакше доспева до оних који су о томе могли век раније само да сањају, истинска генеза умножавања избора везана је за XIX столеће, с идејом да се производи поставе надохват масама. У том смислу, промене у продајним праксама у Паризу у XIX веку веома су поучне. Нови начини продаје помогли су у преосмишљавању објеката као знакова вредности, а не само као знакова статуса, односно статусног обележја. Излози су били у вези с париском буржоазијом, али су садржали и снажан еле- 
мент фантазије и бекства, неку врсту робног ескапизма. Прве робне куће Le Bon Marché и Grands Magasins du Louvre, отворене средином претпрошлог столећа, предочиле су декор који је имао за циљ да људе увуче у продавницу, а потом их прожме робом уз фини додир гламура и романсе, дакле једном врстом потрошачке привлачности. Крај XIX века у Паризу већ добро познаје гламур и светлост рекламе, шарене магазине, менажерију забавних аранжмана, као и систем ланчано повезане робе у робној кући која постаје симбол капиталистичке робне петље. Заправо, роба овде налази своје удомљење, друштво остале робе, особено заједништво робе које није пуки збир већ заводљиви мамац за потрошњу. Робна кућа је кулминација и синтеза једног дугог периода постепеног раста робне петље и она се, у тренутку настанка, јавља већ као зрела конструкција којој не треба много да овлада методологијом излагања и продаје. Али, поред економске, та привлачност одмах задобија и литерарну димензију.

Ваља се зато задржати на Золином роману Коg женскої раја (Аu Bonheur des Dames, 1883) јер је то вероватно најбољи анатомски приказ настанка, развоја и огромног успеха најранијих робних кућа, као и амбиваленција - ефеката петље - на којима се тај успех темељи, као и учинака које он оставља на ткиво књижевности. Наиме, од самог почетка робна кућа Женски рај је приказана као светионик, као место које представља светлост и живот града Париза. Наравно, овде није реч само о метафори него и о буквалном освајању простора јер директор Муре зна да се, највише кроз рат ценама и аранжирање, води битка за што већи простор чији је циљ да се „роба растури на све стране Париза“. Метафора светионика је варљива и речито говори у прилог критике слободе избора. Оно што натписује снагу путоказа јесте изгубљеност у простору робне куће где је гомилање утемељено на седам начела: непрестано увећање капитала, систем сладиштења и аранжирање робе, навођење купаца кроз простор, јефтиноћа која привлачи, снижавање цена, психологија продаје као спој учтивости и грубости, могућност повраћаја робе. Простор робе се описује као захуктала, застрашујућа, огромна, нетранспарентна машина која производи страх (или можда страхопоштовање?), нарочито кад се угасе светла: „Свуда су поигравале велике сенке, слабо се разазнавала нагомилана роба која је својим контурама подсећала на срушене стубове, шћућурене животиње, лопове у заседи и тако уливала страх“ (Зола 1976: 161). Док се промет за четири године повећава пет пута, са осам на 40 милиона франака, простор Женскоі раја нагло се усковитлава, роба (али и људи) постаје лишће ношено ветром. Велика риба једе малу рибу: робна кућа гута околне куће, дућане, читаве улице - коначно прети да засени читав Париз. Она громогласно ступа у режим видљивог и чујног, „пада целом свету у очи“, преплављује зидове, новине, завесе у позоришту (Зола 1976: 252); мада, из наше перспективе, о тријумфалном походу највећма сведочи појава нове 
„врсте“ жене, клептоманке (Зола 1976: 252). Газећи по лешевима старих трговаца-дућанџија, настаје „катедрала модерне трговине“ са 39 одељења, 1800 радника, „цео један свет“ (Зола 1976: 251), иза чијих провидних стакала „у галопу пролазе милиони“ (Зола 1976: 410). Али, као што бива код Золе, није овде реч само о позитивности профита; постоји и дубља психолошка димензија. Власник и директор гради ову велелепну и усковитлану катедралу за женске купце управо како би покорио жене. Али покорене клијенткиње доживљавају његову грађевину сасвим супротно: као бајку. Постоји ту још нешто: чини се и да на тренутке сам роман усваја ритмове робне куће и потрошачког друштва. Поврх свега, жанровски „бајколики“ happy end за који се определио Зола као да сведочи о коначној победи ритмова продаје и у самој књижевној производњи, тако да би и овде било тешко одбранити супротност становишта (1) и (2).

Алфред Деблин је, према Лукачу, говорио да данашњи роман „подлеже двема струјама, једној која води порекло од бајке и другој која води порекло од извештаја. То су струје које не извиру из ваздуха неке естетике него потичу из реалног живота“ (Лукач 1958: 268). Ове две струје повезане су с изворном амбиваленцијом о којој овде говоримо: економија као брига подразумева забринутост због властите судбине у друштвеном пољу, али и старање о себи. Искуство свакодневног живота у капитализму посредовано је старим причама, бајкама, веровањима и митовима у којима је роба, као што је Маркс добро разумео, оживела. Ако су реалистички романи социологични, онда је то пре свега зато што се очекује да се писац пита „из чега и како је та садашњица настала“ (Лукач 1958: 10). Али шта је то нешто? То и јесте вредно запазити: упркос томе што је оскудица и сиромаштво хоризонт живота за велики део популације, егзотика и завођење већ делују, капитализам увек-већ зачарава. У роману Kog женскоі раја актери су вођени сјајем тепиха и ћилима, али не због њихових интринсичних квалитета, колико због посредних асоцијација које воде ка још увек егзотичном и колонијалном Оријенту (Miller 1981). За нас је најбитније да је овде већ на делу оно што се обично приписује каснијим периодима: коришћење и манипулација знаковима, упијање - потрошња знакова као знакова, апсорпција знакова као додатни моменат уживања (Williams 2011: 42). То што је роба и тада имала цедуље које су је уздизале значи да она никад није само роба него се увек нуди још нешто, као конститутивни вишак: лакановци би са задовољством узвикнули: ово је „вишак уживања“, што јесте израз Лаканове трансформације појма вишка вредности. Јер, робна кућа свесно - како је добро показао Зола - преформира људско око, утиче на перцепције и креира и фабрикује начин како се доживљава свет. Кад се уоквирују контуре, људско око је већ предодређено визуелним системима „тржишта штампе“ (Бел-Виљада 2004: 53), „култом штампаних текстова и медиологијом“ (Debray 2007: 11). 
Постоји капиталистичка генеза људских чула, односно, историчност људских чула. То не смемо заборавити ни у случају уметности романа који ове процесе обликује у језику.

Золин Новаи (1891) показује како је деловање главног јунака Аристида Сакара усмерено више на нарушавање правила (чулне) расподеле него на стицање одређеног типа добара. Главни јунак романа не може се свести на Аристотелову назнаку да је похлепа задовољство које потиче од добитка (kerdos) јер поред овог задовољства код њега постоји аспект увлачења других у властити подухват, готово жеља да се преобрази стварност и сасвим подреди тријумфалном походу фиктивног капитала за који је довољно пуко хтење мноштва. Осим тога, роман добро показује како се стари наратив може употребити у новом контексту стицања, односно како капитализам своја морална оправдања не изводи из себе самог већ из ранијих културних образаца. Наиме, на делу је идеја предестинације која је из религије прешла у сферу робне петље: појединац верује да је управо он тај који новац заслужује и коме је он намењен. Зола нас одводи у свет париских финансија: почиње 1864. године, кад је Аристид Сакар, после банкрота, на дну. У првим сценама романа видимо како људи мере свој успех по томе да ли их сви поздрављају или их избегавају; Сакар спада у другу скупину. С инжењером Амланом и госпођом Каролином (брат и сестра), он ствара велики план за оснивање Универзалне банке, чији је циљ да се унапреде трговачке руте у Малој Азији - у стварности, између осталог, у Србији.

Наиме, Зола је искористио стварну епизоду о банци чији је оснивач био Пол Ежен Бонту (Paul Eugène Bontoux), инжењер који је радио код Ротшилда. Бонту је напустио Ротишилдове како би покренуо супарничку финансијску операцију у Аустрији, Србији и југоисточној Европи и 1878. године основао је нову Union Generale, искористивши бум настао услед развоја железничког саобраћаја и изградње Суецког канала. Банка је доживела врхунац 1881, а пад је уследио одмах након тога. Иницијални капитал био је 25 милиона франака, у пролеће 1879. је докапитализована са 50 милиона, у јануару 1881. са још 100 милиона, треће увећање, планирано за јануар 1882, подигло би капитал на 150 милиона; а иницијални капитал је плаћен само једну четвртину Зола је прецизно приказао овај низ. Пропаст Union Generale банке је важан моменат у историји финансија и устоличењу жеље пристекле из рада робне петље јер је први пут огроман капитал обичних људи и ситних трговаца био преусмерен из уобичајеног пословања на берзу, како у обвезницама, тако и у новцу (Kindleberger, Aliber 2005: 67-69). У свету робне петље важи правило big fish eats little fish, па је веома битно што овај роман не тематизује само похлепу великих играча, пре свега Ротшилда већ и похлепу пристојних, „малих“ људи, фанатичних микрокапиталиста увучених у робну петљу, која даје наративну снагу и смисао овом подухвату: 
Зар тај обичан човјек, тај мали капиталист, што је своју уштеђевину скупљао су по су, не заступа лаковјерно мноштво, које је спремно да се повјери, широко мноштво, које се састоји из бројних и добрих муштерија, фанатичну армију, која наоружава кредитни завод непобједивом снагом (Zola 1952: 158).

Занимљиво је како се лако у овај подухват уклапају различити интереси: док Сакар на уму има милионе, Амлан, као изразити католик, машта о верским циљевима - о повратку у Палестину. Он, као и његова сестра, утопијски сматрају да је „новац гнојиво, на коме ће никнути то друштво сутрашњице“ (Zola 1952: 281). Овај зачудни брак религије и берзе је више него индикативан и сведочи о дубљој историјској промени. Зола показује како новац продире у све сфере живота и колико су људи спремни далеко да оду како би га задобили. Оно што код Золе изостаје јесте осуда: он слути да апстракција капитала преузима примат над новцем. Иако се роман зове Новаи, потребан је опрез - Сакар је жртва апстракције коју је сам створио, за њега сам новац и атрибути (статусни симболи) играју тек секундарну улогу. Зола, наравно, неће пропустити да уочи естетизацију иманентну капитализму, окарактерисавши Сакара на следећи начин: „Но он је одувијек био човјек маште, који је све гледао увеличано и који је своја прљава и пустоловна трговања претварао у поеме“ (Zola 1952: 397).

Пре него што се вратимо поетичком проблему економије, потребно је у најкраћим цртама назначити најважније начине на који економија ступа у роман. Наравно, стварносни или цитат из економске сфере је преовлађујући начин повезивања књижевности и економије. То се поготово види у честим тематизацијама новца. Као што умесно примећује економиста Пикети у књизи Кайuйал у XXI векy, „у роману 18. и 19. века, новац је свугде, не само као апстрактна сила, него изнад свега као опипљива, конкретна величина" (2015: 120). Конкретни износи који се помињу у романима Балзака, Флобера, Достојевског или Золе стварају „учинак стварног”, мизансцене за дочаравање начина живота и надметања унутар робне петље. По Пикетију, важност теме новца у књижевности опада после Првог светског рата јер тада свет који је био у позадини његовог значаја доживљава колапс, а главна зараћене стране су престале с конверзијом новца у злато. Пикети каже да новац није случајно нестао из књижевности, а наводи и пример наратора Памуковог романа Сне (2002), који је и сам писац, и каже да за писца нема ништа досадније од причања о новцу и прошлогодишњим ценама. Разлог за то Пикети види у поретку дискурса унутар којег је природа богатства била јасна, или макар задобијала легитимитет у односу на тада важеће норме, што би била још једна потврда да се политичка економија романа непрестано обраћа кризама вредности.

Слично томе, тема друштвеног успона, занимљива у раздобљу устоличења робне петље може се пратити до данас - од Фонтанео- 
вог романа $E \oint и ~ Б р и с \bar{u}$ (1894), у којем се млада девојка удаје за богатог барона, до њених различитих варијација у аутобиографским романима попут Лоренсових Синова и тьубавника (1913) или Џој-

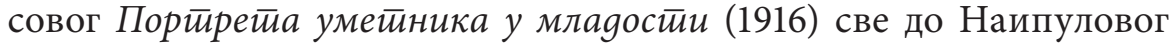
Мистичногі масера (1957) или Белих зуба Зејди Смит (2000) (Robins 2006: 409). Наравно, још један важан правац приступа у економској критици књижевности јесу конвенције и типови ликова. Посматрано из овог угла, лик се не може читати изван његове „сталне апсорпције у тематску, симболичку и структуралну економију текста" (Woloch 2006: 300). Рејмонд Вилијамс оправдано сматра да у модерном класном друштву избор ликова увек указује на претпостављено или освешћену класну позицију (Williams 1977: 302), те у том смислу не постоји „невина“ књижевност која би била изван друштвене поделе карата. Примера има много. Тако, рецимо, Гончаровљев разуђени феноменолошки опис лењивца у Обломову (1859) сведочи о једном готово невидљивом човеку унутар режима поделе рада, али о човеку који, упркос властитом нераду, понавља синтагму: „Ваља радити!“ Простор у коме живи јунак је прилагођен ленствовању: просторија у којој непрестано лежи је multi-purpose спаваћа, гостинска и радна соба (Гончаров 1967: 17-18). Слику лењивца, међутим, прожимају одређене амбиваленције јер чак и Обломов чува, додуше само колико се мора (али зашто се то мора?), decorum „неизбежног, уобичајеног рада“(Гончаров 1967: 19). Сходно томе, он се претвара да ради, смишља план за преуређење властитог имања које укључује „разне нове економске, полицијске и остале мере“ (Гончаров 1967: 20; в. Лошонц, Гвозден 2016: 241-262). Иако није живео у тврдом индустријском капитализму, Гончаров је литерарним путем наслутио да није могућа консеквентна еманципација уколико се до краја прихвати идеологија друштва рада. Слично се може речи за Зайисе из йоgземль (1864) Фјодора Михајловича Достојевског, у којима се проблем друштвеног надметања испољава у формалној логици карактеризације као искидано, фрагментарно приповедање испуњено напетостима.

Истраживање политичке економије романа обратиће пажњу и на логику рационализације - оличену у низу буржоаских категорија као што су тачност, прецизност, формалност, строгост (Moretti 2013: 82) - која прожима његове ритмове: сетимо се, на пример, Холмсове истраге из фотеље, која крвава убиства преводи у „низ предавања“. Вернов бестселер Пуй око светй за 80 gана (1873) уводи нову тачност, ред вожње као категорију; Пешчаник (1972) критикује ту тачност, али не заборавимо да је то једини Кишов роман који ступа у тесну везу с економијом јер она искрсава као неминовност у реконструкцији очевог живота на темељу испитивања стварности произишле из писма. Поменуте категорије нуде „неку врсту наративног задовољства које је у складу с новом регуларношћу буржо- 
аског живота“ (Moretti 2013: 81), све док не дође до његовог неопозивог осипања (које је на уверљив начин описано у Пешчанику како на плану израза, и тако и на плану садржаја).

Видели смо да постоје књижевна дела која се баве главним институцијама тржишне економије као што су потрошач, новац или робна кућа, али обрађују се и слободно тржиште (Шесто поглавље романа Марка Твена Јенки на gвору краљьа Арйура [1889]), ликови предузетника (Дос Пасос, U.S.A. [1930-1936]), незапосленост (Стајнбек, Плоgови інева [1939], Џорџ Орвел, Пуй за Виіан [1937]), тврдичлук (Иво Андрић, Госйођица [1945]), инфлација (Ремарк, Црни обелиск [1956]), загађење (Дикенс, Тешка времена [1854])... Корпорације, међутим, нису толико описиване, будући да су, према Шумпетеровој терминологији, рационалне и антихеројске (Watts, Smith 1989: 297). Једино у Сједињеним Америчким Државама између двадесетих и шездесетих година прошлог столећа постоји разуђена литерарна традиција њиховог описивања (Синклер Луис, Артур Милер, Џон Стајнбек). Романи могу да изразе и крупне промене у економском моралу. Примера ради, двадесетих година у Сједињеним Америчким Државама се смањује обим штедње и расту дуговања. Паралелно се збива промена у ставовима: за неколико година задуживање, које се пре тога сматрало изразито непожељним и опасним, постало је уобичајена пракса. Оваква промена у моралу имала је одређене последице и у књижевности: док позајмице и дугови у романима XIX века по правилу, као у познатом примеру Еме Бовари, воде директно у пропаст (Tratner 1999: 311), Фицџералдов Велики $\Gamma е \bar{u} c \delta u(1925)$ изражава тензије повезане с новонасталом лакоћом задуживања. Писац учествује, премда не без унутрашњих немира, у економском преображају из двадесетих година, „кад је нова врста безбрижности - позајмице и потрошња - проглашена за бољи пут ка богаћењу од штедње“ (Tratner 1999: 313). Трошити а не штедети, овај нови аргумент Кејнс је 1936. претворио у економску ортодок-

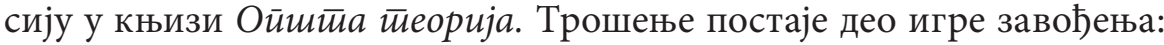
Гетсби не заводи Дејзи тако што троши на њу већ тако што напросто троши (Tratner 1999: 314). У Америчком йсиху (1991) Брета Истона Елиса економски морал иде корак даље. Реч је, наиме, о „упадљивој потрошњи“ (Lefebvre 2005: 43-62), где је трансгресија уприличена у виду понављања убистава као чинова посредованих робом. Лик Патрика Бејтмена исказује оно што бисмо могли, на трагу Етјена Балибара, назвати улитраобјектиивним насилем робне субјективности; ултраобјективно овде значи да се људи третирају као неискористиви остаци, као онтолошке резидуе (Балибар 2011: 61). Ако је роба у овом роману супстрат трансгресије, онда убиство/канибализам фигурирају као образац насилног присвајања (King 2006: 117).

Коначно, кад је реч о променама у економском моралу, ваљало би размислити и о томе како повезати постмодерне економске 
теорије и праксе и превласт пародије, пастиша и апропријације у савременој књижевности и уметности (Osteen, Woodmansee 1999: 32). Примера има много, али ћемо то илустровати цитатом из романа Франческе Дуранти Кућа на Месечевом језеру: „(...) Фабрицио [главни јунак романа] је одједном осетио да није у стању да укроти и прикупи ту масу неразумљивих знакова“ (Дуранти 1991: 38). У оним тренуцима кад се претвара у хаос проза се „везује са сумњом, која се тиче не само светског поретка него и сазнајних и сређивачких могућности књижевности и њеног језика“ (Гловињски 2003: 9-10; Тју 2006: 104-105). Свет је маса неразумљивих знакова у романима Џулијана Барнса, Орхана Памука, Мишела Уелбека, Томаса Бернхарда, В. Г. Зебалда, Давида Албахарија, Владимира Тасића, Пола Остера, Дона Делила...

Али мноштво неразумљивих знакова не спречава да се поставе истраживачка питања. Премда се ретко проблематизује, проблем плаћања за књижевни рад је можда и пресудан за разумевање политичке економије модерног романа. Пол Делани се зато помало јеретички запитао: ко је платио за модернизам? Кад је реч о викторијанској књижевности, одговор је једноставан: читаоци (Delany 1999: 286). Према уобичајеном разумевању, модернизам је типична стратегија помоћу које уметничко дело пружа отпор задобијању робног карактера и измиче социјалним силама које би уметност свеле на предмет размене (Eagleton 1988: 392; в. Бел-Виљада 2004: 125-160). Модернистички роман покушава да превазиђе ширу антиномију: унутрашња динамика капитализма, сазданог на начелима слободе и једнакости, тера га ка феномену масовности, дакле, ка експанзији потрошачких норми. Упркос модернистичкој књижевној економији која је себе отворено изузимала од непосредних веза с економијом књижевног тржишта, Делани истиче да је неко ипак морао да плати уметничко стварање и истражује одакле је долазио новац, шта су модернисти очекивали од њега и на које начине је уметничка пракса била повезана с изворима новца. Он закључује да је кључно улогу за развој модернистичке књижевности имала класа рентијера, која је живела од профита и уштеђевине стицане током неколико генерација у време успона индустријског капитализма и робне петље у другој половини XIX столећа. Рентијери су били највећи потрошачи високе културе (Delany 1999: 287), а постојала је и класа рентијера писаца чије дело карактерише изразита саморефлексивност (Delany 1999: 287). Ова рентијерска класа (Хенри Џејмс, Е. М. Форстер, Голсворди, Томас Ман, донекле и Георг Гисинг и Вирџинија Вулф) постала је временом довољно велика да подржи роман, а не као до тада само ексклузивну лирску поезију. Овај тип културе се ослањао на етос префињености (рафинмана), познат из Џејмсове одбране уметничког приповедања у есеју „Уметност романа“, написаном као реакција на текст Волтера Басена који је тврдио да „оној ко ради за 
плату мора да узме у обзир предрасуде својих муштерија“ (Delany 1999: 288). Говорећи о „култури покровитељства“ Делани подсећа да „ексклузивност није у сукобу са задобијањем робног карактера; она би чак могла бити само његова виша форма“ (Delany 1999: 289) jep се уметнички предмет „не креће истим стазама као производ масовне потрошње“ што само потврђује „способност тржишта да процењује и пушта у оптицај све, од сапуна до репутације“. У контексту робне петље, тешко је одржива тврдња да су модернистички романи „антироба“, они су пре супер-роба: њихов „статус почива на колективном вредновању“ одвојеном од првобитне инвестиције у производњу (Delany 1999: 294). Префињеност модернистичког романа само потврђује правило да на тржишту увек највише вредности задобијају ствари најудаљеније од практичне употребе, а према Фрицу Хаугу, управљање луксузном робом је срж капитализма (Фриц Хауг 1981: 15; в. Смирс 2004: 186-233).

То нас враћа разумевању литературе као вишка. Јасно је да модерно књижевно тржиште укључује различите групе читалаца и произвођача. Како то каже Делани: „Баш као што књижевна вредност може да се дефинише као све оно у делу што йревазилази формалне захтеве жанра, исто тако 'висока' књижевност превазилази тржишне услове под којима је произведена“ (Delany 1999: 294). Према Деланију, модернизам се, као и a fortiori висока књижевност, може сместити у одређене енклаве унутар тржишног друштва, али с релативном аутономијом унутар њих (Delany 1999: 295). Постоје различите улоге у пољу које то омогућују и стварају различите типове репутације. Бурдије је говорио о „културном капиталу“ као о области културних добара која има специфичну логику супротстављену начелу економизма (Бурдије 2003: 167-250). Делани сматра супротно: та специфичност је ограничана економском принудом (Delany 1999: 295).

Политичка економија романа бави се начинима романескне обраде начела, закона, услова и облика економског живота током различитих историјских раздобља. Овде смо, кроз одабране, „теоретичне“ примере скицирали нацрт таквих обрада, као и могуће правце истраживања. Чињеница је да се роман и економска кретања преплићу: „спазму капиталистичке модернизације“ (Moretti 2013: 14) одговара књижевно-формално уобличавање; питање је да ли и у којој мери то уобличавање учествује у преобликовању људи, стварајући тако услове за интерактивност робне петље, где би људи могли да утичу на промене и хуманизацију друштвених односа. Овде се неминовно уплиће марксистичка традиција и њен однос према уметничком раду. Кључна оптужба на рачун капитализма односи се на то да нас он присиљава да своје најбоље стваралачке енергије улажемо у ствари које су утилитаристичке, а „капитал који би се могао уложити у то да барем донекле људе ослободи нужности рада, умјесто тога служи за гомилање још више капитала“ (Eagleton 2008: 98). 
Према уобичајеном критичком приступу, капиталистички начин живота је „посвећен моћи, профиту и материјалном опстанку, а не неговању људског заједништва и солидарности“ (Eagleton 2008: 29). Критичко разумевање уметничког дела као робе потиче од теорија насталих као део марксистичке традиције, дакле из раздобља које је потпуно истоветно времену настанка и устоличења робне петље. Према Марксу, аутентични песник насупрот пискаралу, или грамзивом Аристиду Сакару, производи своје дело „исто као што свилена буба производи свилу, као активну афирмацију сопствене природе“" (Marx 1969: 70). Као што је познато, Марксов поглед је изникао из хуманистичке естетике немачког идеализма, која је прва схватила да успон робног друштва није наклоњен уметности и поезији. Па ипак, мора се имати у виду да је задобијање робног карактера главни друштвени предуслов аутономије уметности (Markus 2001: 5). Ово је потешкоћа која проистиче из саме дубине робне петље,јер роман као производ има разменску вредност и тржишну цену, али за разлику од других предмета нема „стварну“ употребну вредност. Роба-уметност производи не-материјални вишак вредности, потискује властиту направљеност, трагове свог друштвеног настајања и постојања, скрива властито порекло у раду и конструисању (Markus 2001: 15). Робна форма је наметнута уметности јер друштвено неопходно време рада није релевантно за мерење и процењивање људске креативности. Продуктивност духа не би требало, у овом смислу схваћено, мешати с данас владајућом идејом квантитета и профита: она указује на способност производње нових форми, а не на репродукције 'прастарих слика'. Данас би се то пре рекло „креативност“ него „продуктивност“ (в. Moretti 2013: 66), али је и сама реч креативност постала повезана с профитом.

Очигледно је да говоримо о вишку, али он има различите облике, или је перципиран на различите начине - не постоји апсолутни вишак књижевности који би је изузео из света. Политичка економија романа, заинтересована за тачке мешања, моменте урушавања или рушења чистих категорија, управо показује да логику уметности романа не би требало окарактерисати као строго раздвајање између некаквог патоса материјалног живота и чистоте уметничких означитељских пракси. Она циља на брисање чврсте линије која одваја аутономну и хетерономну уметност. Човек ствара и економију и уметност романа као творевине људске праксе. Стога у најбољем случају остајемо при Лукачевој идеји о естетским облицима као структурираним реакцијама на друштвене противречности. Оштра подела на (1) и (2) промашује и (1) и (2) зато што се иза ње крије веровање у одвојеност уметничких од друштвених хијерархија. Поменута подела је, осим тога, погрешна јер заправо верује у то да се бездушни робни свет може победити помоћу лажне душе која предметима намеће квазиуметичко улепшавање, чиме се само 
додатно перпетуира деловање економске логике робне петље која се наводно одбацује. Књижевност може да покуша да покаже „издвајање економског понашања из друштвеног контекста“ (Кока 2016: 91), али онда мора да узме у обзир да и њена одвојеност не може бити заснована без тог истог контекста. Не постоје две површине које бисмо недужно назвали „економија“ и „књижевност“ већ само једна површина људског стварања повезана с одговорношћу, а нико није, као што су то добро показали Флобер, Зола, Достојевски, Кафка или Џојс, у повлашћеном положају, изван или изнад те површине (в. Rancière 2007a: 91-108; Гвозден 2016: 174-175). Према антропологу Дејвиду Грејберу, велики писци не верују у поделу на (1) и (2) већ „имају начин да се суоче с вакуумом, тако што га пригрле. Гледају у бездан, све док бездан не погледа њих“ (Грејбер 2016: 53). Посматрано из угла економске књижевне критике, чини се да модерни роман постепено и самосвесно напушта предрасуду о различитим површима уписивања људске делатности и размишља о томе како да испита границе робне петље и да замисли простор који се простире ван ње (в. Stallabrass 2006: 132). „Ако је пажљиво склопљена прича изашла из моде у књижевности, она је реткост и у обичном животу“, указује социолог економије Ричард Сенет у Кулйури новоі кайийализма (Сенет 2007: 155). Можда би га требало послушати. У том смислу, оштра подела на (1) и (2) била би само још једна пажљиво склопљена прича која је одавно изашла из моде.

\section{ЛИТЕРАТУРА}

Alexander, David. Retailing in England during the Industrial Revolution. London: Athlone Press, 1970.

Балибар, Етјен. Насиле и извилности. Прев. Томислав Медак. Београд: Центар за медије и комуникацију, 2011.

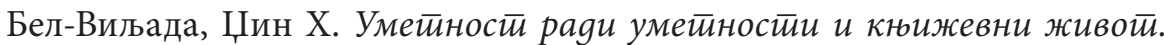
Прев. Владимир Гвозден. Нови Сад: Светови, 2004.

Берсани, Лео. „Реализам и страх од жеље“. Прев. Радана Лукајић. Крајина: часойис за книжевности и кулииуру 2.5 (2002): 47-74.

Browne, Neil M., Quinn, Kevin J. „Dominant economic metaphors and the postmodern subversion of the subject". The New Economic Criticism: Studies at the Intersection of Literature and Economics. Ed. Martha Woodmansee, Mark Osteen. London: Routledge, 1999. 113-128.

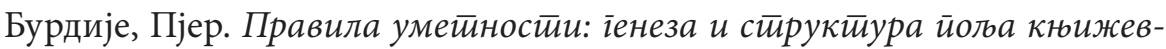
ностии. Прев. Владимир Капор и др. Нови Сад: Светови, 2003.

Watts, Michael, Smith, Robert. F. „Economics in Literature and Drama“. The Journal of Economic Education 20.3 (1989): 291-307. 
Williams, Raymond. Marxism and Literature. Toronto: Oxford University Press, 1977.

Williams, Rosalind. Dream Worlds: Mass Consumption in Late Nineteenth Century France. Berkeley, Los Angeles and London,: University of California Press, 1982. Colin Cremin, Capitalism's New Clothes, London: Pluto Press, 2011.

Woloch, Alex. „Minor Characters“. The Novel. Volume 2: Forms and Themes. Ed. Franco Moretti.Princeton and Oxford: Princeton University Press, 2006. 295-323.

Woodmanse, Martha. The Author, Art, and the Market: Rereading the History of Aesthetics. New York: Columbia University Press, 1994.

Гвозден, Владимир. „Симболизам и естетски режим“. Симболизам $у$ свом и нашем времену. Ур. Јелена Новаковић. Београд: Филолошки факултет, Друштво за сарадњу Србија-Француска, 2016. 167-177.

Ginsburg, Michael Peled, Nandrea, Lari G. „The Prose of the World“. The Novel. Volume 2: Forms and Themes. Ed. Franco Moretti, Princeton and Oxford: Princeton University Press, 2006. 244-273.

Гончаров, Иван. Обломов. Прев. Милован Глишић. Београд: Нолит, 1967.

Грејбер, Дејвид. Уӣойија ирравила: о йехнолоїији, ілуйостии и скривеним раgостиима бирокрайије. Прев. Lucy Stevens. Београд: Геопоетика, 2016.

Delany, Paul. „Who Paid For Modernism?“. The New Economic Criticism: Studies at the Intersection of Literature and Economics. Ed. Martha Woodmansee, Mark Osteen. London: Routledge, 1999. 286-299.

Дуранти, Франческа. Кућа на Месечевом језеру. Прев. Иван Клајн. Београд: Нолит, 1991.

Зола, Емил. Кog женскої раја. Прев. Мирјана Лалић. Нови Сад: Матица српска; Београд: Рад, 1976.

Zola, Emil. Novac. Prev. V. Tecilazić. Zagreb: Kultura, 1952.

Illouz, Eva. Consuming the Romantic Utopia. Love and the Cultural Contradictions of Capitalism. Berkeley: University of California Press, 1997.

King, Anthony. "Serial killing and the postmodern self“. History of the Human Sciences 19.3 (2006): 109-125.

Kindleberger, Charles P, Aliber, Robert Z. Manias, Panics and Crashes. Basingstoke: Palgrave MacMillan, 2005.

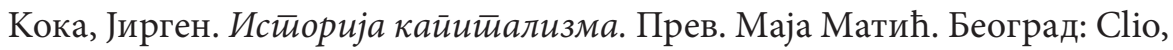
2016.

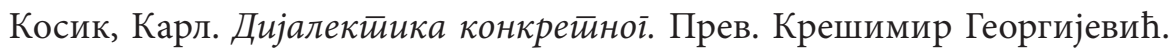
Београд: Просвета, 1968.

Lefevbre, Martin. „Conspicuous Consumption The Figure of the Serial Killer as Cannibal in the Age of Capitalism“. Theory, Culture \& Society 22.3 (2005): 43-62.

Lefebvre, Henri. Kritika svakidašnjeg života. Prev. Predrag Vranicki, Noemi Jungwith. Zagreb: Naprijed, 1988.

Лошонц, Алпар и Гвозден, Владимир. Анайомија робе: оїлеg из крийи-

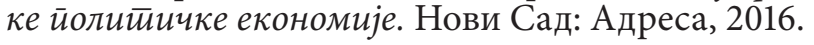


Лукач, Ђерђ. Исйоријски роман. Прев. Фрида Филиповић. Београд: Култура, 1958.

Лукач, Ђерђ. Теорија романа. Прев. Касим Прохић. Сарајево: Свјетлост - Веселин Маслеша, 1990.

Luhmann, Niklas. Liebe als Passion. Zur Codierung von Intimität. Frankfurt/M: Suhrkamp, 1982.

Маркс, Енгелс. Дела, йом 3. Београд: Просвета, 1977.

Markus, Gyorgy. „Walter Benjamin or the Commodity as Phantasmagoria“. New German Critique, 83 (2001): 3-42.

Marx, Karl. Resultate des unmittelbaren Produktionsprozess. Frankfurt am Main: Neue Kritik, 1969.

Miller, Michael. The Bon Marche: Bourgeois Culture and the Department Store, 1869-1920. Princeton, New Jersey: Princeton University Press, 1981.

Moretti, Franco. „On the Novel“. The Novel. Volume 2: Forms and Themes. Ed. Franco Moretti, Princeton and Oxford: Princeton University Press, 2006. ix-X.

Moretti, Franco. The Bourgeois: Between History and Literature. London, New York: Verso, 2013.

Osteen, Mark and Martha Woodmansee, „Taking account of the New Economic Criticism: An Historical Introduction". The New Economic Criticism: Studies at the Intersection of Literature and Economics. Ed. Martha Woodmansee, Mark Osteen. London: Routledge, 1999. 2-41.

Pavel, Thomas. „The Novel in Search of Itself: A Historical Morphology“. The Novel. Volume 2: Forms and Themes. Ed. Franco Moretti. Princeton and Oxford: Princeton University Press, 2006. 4-31.

Паскал, Блез. Мисли. Прев. Јелисавета Ибровац-Поповић и Миодраг Ибровац. Београд: Нолит, 1988.

Postone, Moishe. Time, Labour, and Social Domination: A Reinterpretation of Marx's Critical Theory. Cambridge: Cambridge University Press, 1993.

Рансијер, Жак. Естиезис. Прев. Тања Пекић и др. Нови Сад: Адреса, 2014.

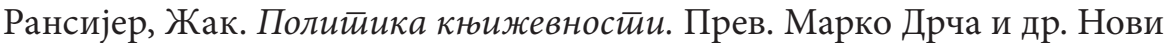
Сад: Адреса, 2008.

Rancière, Jacques. The Politics of Aesthetics. Tr. Gabriel Rockhill. London, New York: Continuum, 2007.

Rancière, Jacques. The Future of the Image. Tr. Gregory Elliott. London, New York, Verso, 2007.

Debray, Régis. „Socialism: a life-cycle,“ New Left Review, 46 (2007): 5-28.

Robins, Bruce. „A Portrait of the Artist as a Social Climber: Upward Mobility in the Novel“. The Novel. Volume 2: Forms and Themes. Ur. Franco Moretti (ur.). Princeton and Oxford: Princeton University Press, 2006. 409-435.

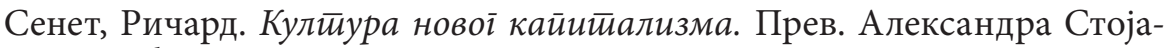
новић. Београд: Архипелаг, 2007.

Stallabrass, Julian. Contemporary Art: A Very Short Introduction. Oxford: Oxford University Press, 2006. 
Shell, Mark. The Economy of Literature. Baltimore: Johns Hopkins University Press, 1978.

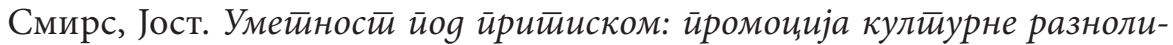
костии у gоба ілобализације. Прев. Наташа Ваван. Нови Сад: Светови, 2004.

Thompson, James. Models of Value: Eighteenth Century Political Economy and the Novel. Durham, NC: Duke University Press, 1996.

Тју, Филип. Савремени брийански роман. Прев. Наташа Ваван Пралица. Нови Сад: Светови, 2006.

Tratner, Michael. „A man in his bonds: The Great Gatsby and deficit spending“. The New Economic Criticism: Studies at the Intersection of Literature and Economics. Ed. Martha Woodmansee, Mark Osteen. London: Routledge, 1999. 311-321.

Флобер, Гистав. Госйођа Бовари. Прев. Цвета Котевска. Суботица: Минерва, 1988.

Фриц Хауг, Волфганг. Критиика робне естиетиике. Прев. Оливера Петровић и Зоран Гаврић. Београд: Издавачко-истраживачки центар ССО Србије, 1981.

Huxley, Aldous. Brave New World Revisited. London: Chatto \& Windus, 1959.

Campbell, Colin. The Romantic Ethic and the Spirit of Modern Consumerism. Oxford: Blackwell, 1987.

Carrier, James G. Gifts and Commodities. Exchange and Western Capitalism since 1700. London and New York: Routledge, 1995.

Comyn, Sara. Political Economy and the Novel: A Literary History of "Homo Economicus". Cham: Palgrave, MacMillan, 2018.

Džej, Martin. Dijalektička imaginacija. Prev. Mario Suško. Sarajevo: Svjetlost, 1982.

Vladimir Grozden

The Narrative and the Commodity Loop:

Towards a Political Economy of the Modern Novel

\section{Summary}

This paper attempts to analyze how the elements of the commodity loops enter the genre of the novel. The change which occurred in last decades of the $19^{\text {th }}$ century required a particular space and new "types" of people with an embedded concept of consumption as an extraordinary sensual experience. At the same time, there also appeared the transgressive social types: the first department stores "created" kleptomaniacs, the growing possibility of traveling produced a new illness of "crazy travelers", and the figures of the dandy and flaneur described new types of bour- 
geois subjectivity that would soon become widespread. The aim of the paper is not to demonstrate a mere application of the economy on literature, but to show how the looping effects of commodities enter the network of novels and how the novel tries to re-shape that same loop. This approach involves an analysis of the well-known novelistic thematizations of the turbulent world of goods, formal innovations related to the treatment of commodity values, as well as the different types of people created by the commodity loop. The political economy of the novel, interested in mixing points, moments of collapsing or demolishing pure categories, shows that the logic of the art of novel should not be characterized by a strict separation between the pathos of material life and the purity of artistic signifying practices. It aims to erase a solid line that separates the autonomous and heteronomous art. Therefore, at best, we remain at Lukács' idea of aesthetic forms as structured reactions to social contradictions. The sharp division between economy and literature misses both economy and literature because it hides behind the belief in the easy separation of art from social hierarchies. Literature can strive to prove "the separation of economic behavior from the social context", but then it must take into account that its own separation cannot be founded without that same context. However, observed from the perspective of economic literary criticism, it seems that the modern novel gradually and self-consciously abandons prejudices about the different surfaces of inscriptions of human activity and contemplates how to examine the boundaries of the commodity and to conceive the space that goes beyond the workings of the commodity loop.

Keywords: literature, capitalism, aesthetics, commodity, subjectivity, modernity, creativity, productivity, Romanticism, Modernism

Примљен: 1. маја 2019.

Прихваћен за објављивање: 26. јула 2019. 